\title{
Local Communities Participation In China-Pakistan Economic Corridor (CPEC): The Case Of Balochistan
}

\author{
Siraj Bashir \\ Department of Social Work \\ University of Balochistan \\ Muhammad Arshad \\ Department of Social Work \\ University of Karachi \\ Sadia Barech \\ Department of Social Work \\ University of Balochistan
}

\begin{abstract}
In development, community participation has become a crucial aspect to encourage community interest, ownership and sustainability of projects. Development by itself relates with human development, therefore the participation of the people in their own development is very essential. This mega Chinese plan is to spend 62 billion US dollars to build China Pakistan Economic corridor and the Gwadar port. China-Pakistan Economic Corridor (CPEC) is a collection of development projects, which is intended to rapidly expand and upgrade Pakistani infrastructure, as well as deepen and broaden economic links between Pakistan and China. According to Government of Pakistan, the corridor Gwadar-Kashger would be a game-changer for Pakistan and will certainly put the province of Balochistan in new ranks of development sector. This research paper discusses the involvement and participation of local communities in CPEC project in Pakistan using a case study of local communities in Balochistan. The study examines two key opinions: community membership in the CPEC decision implementing process; and the contribution of CPEC project towards Balochistan development. The study includes interviews and document analysis. A sample of 100 multi-stakeholders (ordinary community members, politicians, Government officials, NGOs representatives, fishermen and businessmen) will be selected through a pre-structured interview schedule using random and purposive techniques for primary data. The data will be analyzed with the help of Chi-Square. The findings of the study may help to policymakers, project experts and national and international organizations to introduce new participatory approaches to ensure local communities participation in development projects, particularly in the CPEC project.
\end{abstract}

Keywords: Local Communities Participation; China_Pakistan Economic Corridor, Balochistan. 


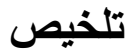

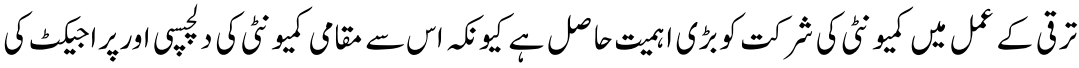

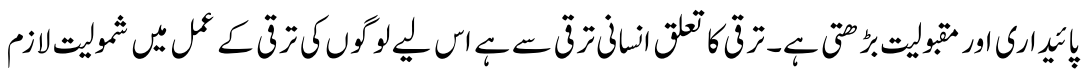

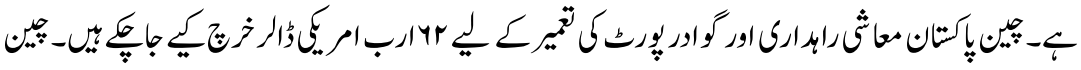

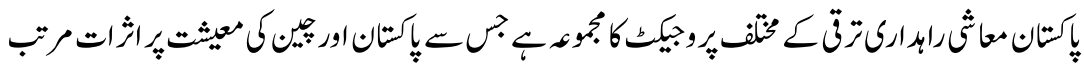

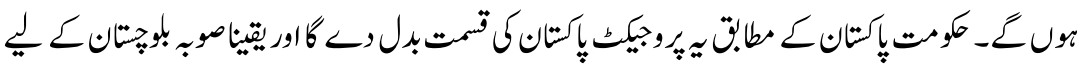

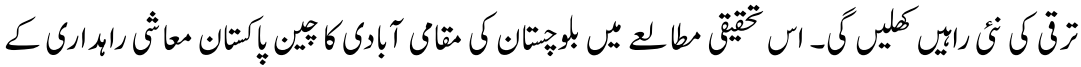

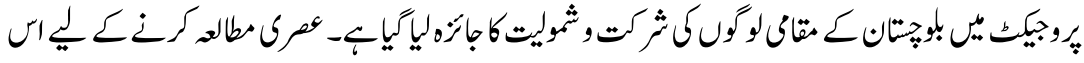

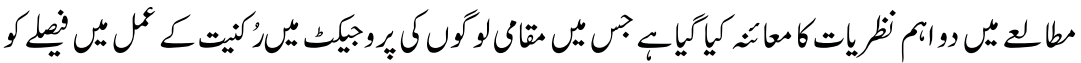

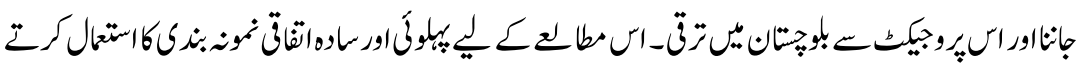

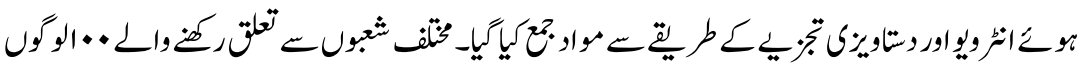

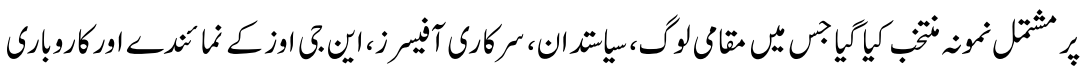

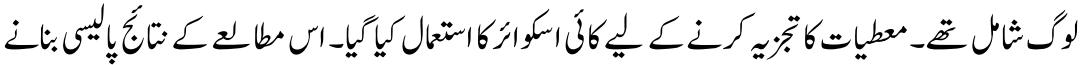

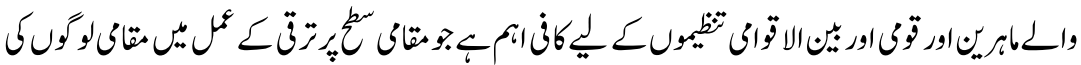

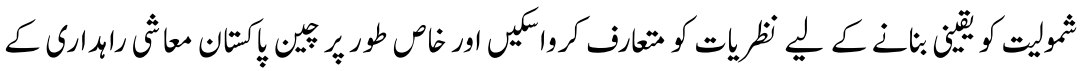

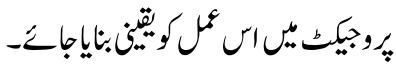

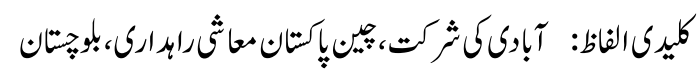

\section{Introduction}

Development is a method to enhance and build the social, political, economic and cultural advancement in a particular area or community for the betterment of that selected area, this include justices, equality, well facilitate living slandered, equal opportunities as well as security and improved facilities for health, education, welfare, housing etc. As Liebenberg \& Theron (1997) indicated that development itself could be a process of enhancing and empowering individuals to get higher management over their resources or lives as people and as a member of a community. It suggests that development aims to build individuals and community's skills so as to prepare and improve native resources toward meeting the fundamental desires.

Development has been thought-about as a multi-dimensional method, relating main contributory factor in a social order, the rise of financial stability, a decrease of disproportion and reduction of privation. Development doesn't suggest solely 
economic improvement however conjointly the advance in human dignity, selfsufficiency, security, equity and value (Khwaja, 2004). According to Davids (2005), development means improvement in the whole walk of life, which includes the economic, social, political, cultural, psychological and environmental.

The concept of development gained a great value after World War II. The simple way to measure development with different indicators such as gross per capita income. This perspective was linked with economic development and economic growth. The countries with sustained growth of GNP or per capita income were measured as developed. This idea of development supported by international organizations such as World Bank and other regional trends and national governments in the world. World Bank, uses Gross National Product per capita (GNP p.c.) to divide the countries of the world into development categories. Lowincome countries are defined as those with a GNP p.c. figure in 2001 of US\$745 or less, lower-middle-income countries have US\$746-2,975, upper-middleincome countries US\$2,976-9,205 and high-income countries are those with GNP p.c. of US\$9,206 or more (Willis, 2005).

During 1970s-80s, a new idea of development appeared where development was considered as a condition of human well-being rather than as the condition of GNP. According to declaration (1974) "the basic concern should be human; human beings have basic needs: food, shelter, clothing, health and education. Any process of development that does not lead to their realization or even worse disrupts them is a travesty of the proposal of development" (United Nations, 1974).

In the late 1980s, the United Nations Development Program (UNDP), this measure divided into three dimensions of development in relation to human wellbeing: a long and healthy life, education and knowledge and a decent standard of living. The general concept of this approach was to eliminate poverty and inequality in different societies. After this approach, development is understood and measured not only in economic feature but also in terms of social well-being: health, education and political structure and a standard live. That's why, it has been said that development is not only to be measured in terms of growth, but is to be described as growth and social change (UNDP, 2014).

The human well-being concept of development referred that all human being should achieve moral and material well being. "the ultimate purpose of development is to provide every one with ever increasing opportunities for a better life. It, therefore, requires an equitable distribution of income and other social resources in order to promote justice and efficient production, to raise levels of employment substantially to expand and improve facilities for education, health, nutrition, housing and social and cultural well-being. The qualitative and structured changes that development thus imposes on society must go hand in hand with economic progress while racial, ethnic and social inquilinity must be 
substantially reduced. There are decisive factors in hastening development and hence must be handled with dynamism". The concept of development in this study, linked with the enhanced living standard of people at first place in communities through executing of development programs (Food Agriculture Organization, 1975).

In development programs, community participation has become an important facet to encourage community interest, possession and sustainability of projects. Development by itself relates to human development, so the participation of the folks in their own development is extremely essential. Therefore, Communities' participation has a very high status over the last three decades. According to Marsland (2006) participation is a joint process, the public in general voluntarily, or due to arguments, accord to work together with remotely decided advancement venture, regularly by contributing their work and assets as an end-result of some normal advantages. World Bank (1990) elaborated that participation as a method through that shareholders manipulate and shares management over development programs and choices and resources that have an effect on them.

Therefore, based on the above concepts of participation and development, we will say that participation may be a vital method of empowering people within the development process. In a simple way, participation may be a process which provides power to the individuals to advance their lives." On the other hand, the involvement is important for voluntary action and not forced by external. So as for the people to participate effectively, they need to be willing to participate in development projects" (Pawan, 2014).

The Chinese plan to invest over than $\$ 62$ billion dollars in Pakistan to strengthen the relationship between each country. China-Pakistan Economic Corridor (CPEC) is a gathering of improvement ventures, which incorporates network, vitality, and foundation ventures. Evaluated to be about 3,000 km long, it may connect Gwadar port to China's Xinjiang region. Which is planned to quickly extend and update Pakistani foundation, and also develop and widen monetary connections among Pakistan and China (Malik, 2014). This Chinese mega venture has not just offered extraordinary open doors for the monetary flourishing of China and Pakistan, however, will likewise give an incredible enhance to their key significance. As indicated by Bhattacharjee (2015) the passage GwadarKashgar would be a distinct advantage for Pakistan and would assume a vital job in the advancement of Balochistan. The CPEC is viewed as a one of a kind key task that guarantees to thrive in Pakistan and has shepherded in another time of closeness with China.

With such a huge investment in a country which is already in a financial crisis and facing some severe issues in local and international politics. Such confederation 
will directly affect the business and political conditions of the country at the local level. Furthermore, there are possible changes the development of China Pakistan Economic Corridor will directly influence the business and demographic cycle, one of the major reason for such development is the deepness of sea level of Gwadar and its geostrategic location of Balochistan.

Balochistan is a resource-rich province covering forty three $(43 \%)$ percent of the land area of Pakistan. It has an about seven hundred (700) km-long coastline on the Arabian Sea, which connects Pakistan to the Persian Gulf and Strait of Hormuz. It has one of the largest gold mines (RekoDiq) and reservoirs of iron and copper (Saindak mines) in the world (Mir Sher \& Muhammad). Under the common frame of the CPEC, a great number of energy, infrastructure and port-related projects have been started in Balochistan. In the past, no concentration was given to the development of local people of Balochistan and historical facts show that the area was totally ignored. The people of Balochistan raised several questions on this regard but no attention was given to them. The CPEC major parts fell in Balochistan province, but the local people of the province is being ignored in the overall process of the project activities. As Quddus stated (2018), that we are not against of the project but demanded due rights of local people under the CPEC and more than Rs5,000 billion is being spent on the project, but local people are not getting even one percent participation. The CPEC can help diminish the distrust among the Baloch people if local people can be involved in CPEC project. The project can succeed with the participation of local people. Therefore, nowadays in the world, every country believes local people participation in development projects and it is also an essential approach for public development.

This research paper discussed the involvement and participation of local communities in CPEC project in Pakistan using a case study of local communities in Balochistan. The study examined two key opinions: community membership in the CPEC decision influence power; and the contribution of CPEC project towards Balochistan development. The research was directed by five interconnected research questions: (1) how local people perceive their attributes towards community participation in CPEC project; (2) what are the responsibilities and duties of local people in CPEC project; (3) to what level do local people participate in the CPEC decision-making process; (4) what are the factors that limited local people in CPEC project; and (5) what are the major consideration of local people on the donation of CPEC towards Balochistan development.

\section{Review Literature}

\section{Chinese Economic Corridor's Mega Venture with Pakistan}

China always remains the most trustworthy ally at global political, economic, social and cultural stage. There is no uncertainty that Pak-China reciprocal 
relations are solid since the start (Arif,1984). Every China and Pakistan dealt with their relationship in an extremely valuable and explained strategy. Pakistan and China helped each other at the vital occasions. Pakistan additionally upheld the entrance of China in the UN framework and perpetual individual from the UN Security Council (Iqbal, 2011). On the opposite side, China additionally bolstered Pakistan amid the critical crossroads and upheld Pakistan manufactured its military and financial abilities, for example, Heavy Mechanical Complex, Taxila in 1968, Ordinance Factory in East Pakistan in 1970 and Aero-nautical Complex (Tai, 2017).

In the 1980s, 1990s, and 2000s once sanctions obligatory by the USA, (Dr. Shah, 2016). In November 2014, the Chinese government declared that it'll finance Chinese corporations to create $\$ 45.6$ billion worth of energy and infrastructure projects in Pakistan as a part of the China-Pakistan Economic Corridor (CPEC). China will invest around $\$ 33.8$ billion in numerous energy projects and $\$ 11.8$ billion in infrastructure projects-roads, railway lines etc, which is able to be completed by the end of 2020 (Dr. Sadaf \& Zafar, 2017). On 20 April 2015, Islamic Republic of Pakistan and China signed an agreement to start work on the $\$ 46$ billion agreement, that is about 20\% of Pakistan's annual GDP with about $\$ 28$ billion in immediate projects and the rest allocated for projects in the pipeline (CPECNEWS, 2017).

This Corridor is an assortment of development projects that involve the linking of Gwadar Port to China through highways, railways, oil and gas pipelines, and an optical fiber link. Major physical infrastructure to be designed includes 2,700kilometre highway stretching from Kashgar to Gwadar through Khunjrab, railways links for freight trains between Gwadar and Khunjrab linking to China and having possible regional connectivity with Afghanistan, Iran, and India, and the Karachi-Lahore motorway. The project will commence the renewal and extension of the Karakorum Highway that links Xinjiang with Pakistan's northern region Gilgit-Baltistan and Khyber Pakhtunkhwa (Wang, J, 2015).

It will contain for the most part several areas of cooperation as well as economic and technical joint cooperation, construction of road and rail links, fiber optic cable projects, development of industrial zones and benefits to regional countries can develop relations. The linking of China with Gwadar port provides numerous financial benefits. Gawadar once equipped can link Central Asian Regions (CARs) to outside world. Gwadar-Kashgar Economic Corridor (GKEC) can decrease 12000 miles between China and the Middle East. A smooth access to the Middle East, African, and EU markets for Chinese exports (CPGS, 2014).

China intends to fabricate oil storerooms and a refinery at Gwadar Port, with oil transported to its Xinjiang Uighur Autonomous Region through street and pipeline. This will permit it to move vitality and supplies to landlocked China 
while not looking at the Strait of Malacca, that may be hindered by the U.S. or then again India should threat escape inside the locale. The undertaking will result in being developed in western China, where strains are stewing from exercises by central separatists (Qama, 2017).

Pakistan is deliberately an extremely fundamental goal for China since it joins China to three locales, the South Asian district, the Middle East and Central Asia. The China- Pakistan Economic Corridor (CPEC) intended to be produced with Chinese venture is predicates to more help financial and vital participation between the two nations. Chinese Premier Li Keqiang accentuated the improvement of the CPEC amid his May 2013 visit to Pakistan. The passageway can interface Gwadar Port in Balochistan to Kashgar in north-western China, which can assemble Gwadar not just totally operational anyway a huge remote ocean port in the region (Zimmerman, 2015). Opened for tasks in 2007, the control of Gwadar Port was exchanged to China's state-owned China Overseas Ports Holding in February 2013. From that point forward, Gwadar is experiencing a genuine development to demonstrate it into a full-fledged, deep-water beneficial port. When the hallway is developed, it will fill in as an essential passage for exchange among China and the Middle East, and Africa. The hallway is relied upon to cut by 12,000-kilometre the course that Middle East oil supplies should now take to touch base at Chinese ports (Mahmood, 2016).

\section{Balochistan and CPEC}

Balochistan covers most of the land mass of country and the smallest in terms of population. When considered against socio-economic ranks of other provinces, Balochistan is the least developed. Its community is still snowed under with tribal structures. The province is rich in resources but has unskilled population due to the negligence of policymakers is an interference in using those resources to the utmost. The failure of provincial governments to improve the capacities of the population and its institutions has also considerably contributed to the underdevelopment of the province.

According to PILDAT report (2012) that Baluchistan's literacy rate sets at fiftyone-point five percent and requires great attention. The unemployment ratio is twenty percent have also reasoned a low annual growth rate. The Institution findings recommend that Balochistan has had a weak development presentation over the past 70 years and its GDP per capita is also the lowest as compared with other provinces of Pakistan. Since the beginning of Pakistan, unusual notice was taken on the province while not have of infrastructure and weaknesses in institutions affected the result and performance of the plans. The development programs that were executed in past did not bring advantageous change, thus which speared disappointment between the residents of the region as their interest for more noteworthy financial improvement was not replied. To 
tackle the objections of people, completely different governments tried, however, all of them have failed. However, the provincial government lacks the capacity, moreover because the resistance from the social group leaders, has barred the method.

According to the findings a report (2005), the literacy rate in Balochistan is very low, which was only 26 percent. As compared with other provinces Balochistan also bags behind in other socio-economic indicators, safe drinking water, sanitation, education and health (Maria, 2013). The majority of the population of Balochistan lives in rural areas where majority of them don't have the basic facilities such as education, health, housing and etc. In contrast, 70-80 percent of villages, in other parts of the country, have the basic facilities. Balochistan is the most backward province of the country but very rich regarding natural resources, natural gas is the country's main energy source and accounts for fifty percent of the total energy use. The most produced gas of Balochistan is use in country which is sixty eight (68) percent. But, unfortunately, only four districts in Balochistan get gas. The gas was discovered in 1953 at Sui and it was reached to Rawalpindi 1964. Unfortunately, the capital city of Balochistan, Quetta, received it after forty three (33) years of the discovery

The anger of local people of Balochistan against government or state has shaped over these matters. A number of people specially nationalist parties and youth have warned the government and state against more development in province unless they are taken into assurance and given equitable share (Frederic, 2006). Out of almost 20,000 students who graduate in Balochistan each year, only 1,800 are able to get jobs. Unemployment and poverty are the major factors behind their anger (UNDP, 2016). Secondly, the lack of human development chances have also created many issues in Balochistan. Without solving these issues it will be very difficult for the government to get success results from the CPEC (Pakistan is a Resilient Country, 2012).

The development of this Corridor agreement is a most important mission which is considered a game changer for the Balochistan, country, and region as well. According to government officials and experts, this project will open up a number of new opportunities for both countries particularity Balochistan. It will be the financial hub and will donate towards the advancement of Balochistan, bringing about tending to the different social financial issue of the province. According to the Ministry of Planning, Development, and Reform the following projects have been planned in Balochistan under CPEC. 
Table: 1

CPEC-energy projects for Balochistan

\begin{tabular}{|l|c|c|c|}
\hline Projects & Region & MW & Estd. Cost (US\$ M) \\
\hline Gwadar Coal Power project & Gwadar & 300 & 360 \\
\hline $\begin{array}{l}\text { HUBCO coal power plant } \\
\text { 1X660 MW }\end{array}$ & Hub Choki & 1320 & 1940 \\
\hline Gaddani Power Park Project & Bela & & \\
\hline i) 2x660MW & & 1320 & 3,960 \\
\hline ii) Jetty+ Infrastructure & & & $\mathbf{7 , 4 6 0}$ \\
\hline Total Energy Projects & & $\mathbf{2 , 9 4 0}$ & \\
\hline
\end{tabular}

Source: Ministry of Planning, Development and Reform, 2017

\section{Methodology}

The study was conducted in Makran division (Turbat, Gwadar and Punjgur), Balochistan. The data collected from the local communities and government officials were selected through pre-structured questionnaire from three districts. Quantitative method was used to collect general and focused data and conclusions. The purposive and convenience techniques of non-probability sampling method were applied and the sample size was 100 respondents.

Table: 2

Numbers of the respondents

\begin{tabular}{|l|c|}
\hline Category & Total \\
\hline Community people & 50 \\
\hline Government official & 20 \\
\hline Political parties workers & 20 \\
\hline NGOs representatives & 10 \\
\hline Total & $\mathbf{1 0 0}$ \\
\hline
\end{tabular}

\section{Results and Discussions}

The involvement of the local communities in any project is essential to the success of development practice. The absent of local community participation in the project may create problem which leads towards failure. Local people participation is obligatory and indispensable for project success. The majority of the development programs particularly planned by International Organizations such as World Bank, IMF, and Asian Development Bank necessitate including the local people in the structuring, executing and observing of improvement ventures. Be that as it may, the potential advantages joined with participatory methodology are disputable. 
Table: 4.1

Respondents knowledge about CPEC projects detail

\begin{tabular}{|l|c|c|}
\hline Do you know about the CPEC projects detail & Frequency & Percentage \\
\hline Yes & 37 & $37 \%$ \\
\hline No & 59 & $59 \%$ \\
\hline Some extent & 4 & $4 \%$ \\
\hline Total & $\mathbf{1 0 0}$ & $\mathbf{1 0 0 \%}$ \\
\hline
\end{tabular}

\section{Data Interpretations}

The survey indicates that majority of the participate (59\%) don't have any knowledge about CPEC projects detail. The second highest respondents who were $37 \%$ said that they know about the projects and the most respondents were government officials and politician who know about CPEC projects.

The findings show that majority of people don't have CPEC projects details. Therefore, it is very essential for the government to involve local people of Balochistan in CPEC because there absent may create problems for the project. For this purpose the Government of Pakistan should conduct different sessions though these sessions people should be awarded about the detail of CPEC.

Table: 4.2

Participant's contribution in the development planning process

\begin{tabular}{|l|c|c|}
\hline $\begin{array}{l}\text { Have you participated in initial } \\
\text { process of CPEC programs? }\end{array}$ & Frequency & Percentage \\
\hline Yes & 7 & $7 \%$ \\
\hline No & 93 & $93 \%$ \\
\hline Total & 100 & $100 \%$ \\
\hline
\end{tabular}

\section{Data Interpretations}

For the above table's question very low ( $7 \%$ only) belong to government departments and political parties, $93 \%$ respondents have not participated in CPEC planning phase. The survey directly indicated that most of the respondents have not participated in any kind to CPEC project which isn't a good sign for the residents.

From the findings of the study, we conclude that general people are not being involved in the initial stage of the project and just very limited government official were involved. Actually, the success of any project depends on local people participation. All political parties, raised their concerns on CPEC project which is not a positive sign for the project. Therefore, federal government should talks with all parties to finish their concerns regarding it. 
Table: 4.3

Respondents' perception about their Opinion in CPEC

\begin{tabular}{|l|c|c|}
\hline $\begin{array}{l}\text { Respondents view point value by related } \\
\text { authorities? }\end{array}$ & Frequency & Percentage \\
\hline Yes & 4 & $4 \%$ \\
\hline No & 96 & $96 \%$ \\
\hline Total & 100 & $100 \%$ \\
\hline
\end{tabular}

\section{Data Interpretations}

Question was asked to the respondents that weather their opinion was considered by the related authority regarding CPEC projects most of respondents $96 \%$ mentioned that their view point was not considered while only $4 \%$ respondents mentioned that their opinion was considered by the CPEC project authorities.

The ignorance of local people in such projects will create a number of socioeconomic and political problems for government and other stockholders and leads towards the failure. If we look at the past projects from different areas of the World than we concluded that without local people participations there will be no success.

Table: 4.5

Native resident's contribution in the resolution implementing procedure

\begin{tabular}{|l|c|c|}
\hline $\begin{array}{l}\text { Native resident's contribution in the } \\
\text { resolution implementing procedure }\end{array}$ & Frequency & Percentage \\
\hline Yes & 3 & $3 \%$ \\
\hline No & 97 & $97 \%$ \\
\hline Total & 100 & $100 \%$ \\
\hline
\end{tabular}

\section{Data Interpretations}

Involvement of local people in the decision process is very low (3\% only) and they belonged to government departments and political parties, the majority of respondents $(97 \%)$ reported that they have not involved in CPEC decision.

The study indicated that local people decision making is very much important and necessary, but unfortunately, they are misfortunate to make decisions regarding the project which related to them. 
Table: 4.6

Factors limited local people participation in CPEC

\begin{tabular}{|l|c|c|}
\hline Factors influence & Frequency & Percentage \\
\hline Lack of federal Government interest & 39 & $39 \%$ \\
\hline Lack of proper skills & 13 & $13 \%$ \\
\hline Fear & 10 & $10 \%$ \\
\hline Absence of civil society & 11 & $11 \%$ \\
\hline $\begin{array}{l}\text { Lack of local people's awareness } \\
\text { about their rights }\end{array}$ & 12 & $12 \%$ \\
\hline Weak political parties in Balochistan & 15 & $15 \%$ \\
\hline Total & $\mathbf{1 0 0}$ & $\mathbf{1 0 0 \%}$ \\
\hline
\end{tabular}

\section{Data Interpretations}

It is observed about $39 \%$ had the view that the federal government is the main factor that limited local people participation in CPEC project. According to $15 \%$ of respondents Balochistan based political parties are weak to fights for our rights. $13 \%$ viewed that they don't have proper skills for CPEC project which is also considered a factor but to the negligence of policymakers. $12 \%$ said that the majority of people don't have awareness about their basic rights which also limited local people in the project. Whereas $11 \%$ and $10 \%$ viewed that absence of civil society and fear which limited us. Majority of people were complaining against Federal Government because according to them federal government is not taking any positive step to boost local communities skills.

Findings indicated that, there are multi reasons which are creating problems for local communities participation if the federal government take some special initiatives in this regard than it might be possible to reduce their concerns. Secondly, provincial and federal governments should establish technical institutions to build local people skills.

Table: 4.7

The contribution of CPEC project toward Balochistan development

\begin{tabular}{|l|c|c|}
\hline $\begin{array}{l}\text { Contribution of CPEC project } \\
\text { toward Balochistan Development }\end{array}$ & Frequency & Percentage \\
\hline Yes & 29 & $29 \%$ \\
\hline No & 71 & $71 \%$ \\
\hline Total & $\mathbf{1 0 0}$ & $\mathbf{1 0 0 \%}$ \\
\hline
\end{tabular}

\section{Data Interpretations}

About $71 \%$ had the view that there will be no contribution towards Balochistan development. According to them CPEC is not for us and we will be in minority. 
$29 \%$ said that CPEC will contribute toward Balochistan development but they also showed some grievances.

\section{Conclusions}

Study on the community's participation in CPEC concludes that the interest of local individuals in CPEC ventures is one of all goals of this investigation work. Also, from the examination, numerous components are realized that encourage to work out the character of support at the grassroots dimension. The dimension of cooperation being developed ventures in the investigation zone is extremely unimportant. Interest in hopes to be confined exclusively to people with organization. the generally open and social and political backwardness are gravely denied of including in nearby dimension advancement ventures.

At times, it is seen that individuals' delegates in Balochistan are under enormous strain to be obliged by the bearings of the government. In some uncommon cases, open gatherings are additionally held for recognizable proof of nearby needs. Be that as it may, the activities are not very many and don't importantly affect the by and large improvement process. As a rule, these activities are preferably close to home over institutional.

Nonetheless, step by step community individuals are winding up more cognizant as natives and accordingly, voices are raising from the common society associations and additionally political gatherings for participatory administration at nearby dimension for better and economical administration of open assets.

\section{Recommendations}

China and Pakistan must ensure native people assurance, contribution, and feeling of attachment towards the CPEC projects, particularly in Balochistan. Though this two nations gain the advantages from CPEC. Advancement doesn't mean just financial enhancement yet additionally the enhancement in human poise, confidence, security, equity, and value. It is, subsequently, an obligation of the government to return to CPEC designs and suggestions and for the Balochistan government to profit itself of this one-time opportunity from CPEC. In perspective of the discoveries of the examination, a few proposals are proposed to make the advancement procedure in this nation more individuals situated:

1. Chinese authorities should seriously consider the local people viewpoint regarding the mega project.

2. Technical abilities regarding the extent of CPEC should be expanded at the neighborhood level. Compelling measures ought to be taken to 
manufacture limit of the Balochistan with the goal that they can embrace and do local advancement exercises freely.

3. Balochistan ought to be given with significant independence. Impedance from the government must be halted. In the meantime, Balochistan ought to be kept outside the complex bureaucratic system beyond what many would consider possible. In this manner, vital changes in the legitimate system ought to be made.

4. The chosen delegates at commonplace dimension are for the most part unconscious about the advantages of participatory advancement approach. The absence of learning in such a manner on their part may have added to their misconception and misguided judgment. Propelling preparing projects or workshops may help change the attitude of the chosen delegates with respect to participatory practices being developed medications. They can express their requests legitimately and make important commitments to nearby improvement arranging.

5. Stakeholder examination ought to be done before taking any task. Furthermore, interest of key partners (Nationalists political gatherings) being developed arranging must be guaranteed with the end goal to make advancement ventures feasible and suitable.

6. key stakeholders (political parties)should be counseled before taking up any tasks and have been incorporated into the execution procedure.

\section{References}

Arif, K. (1984). Documents on China-Pakistan Relations. Lahore: Vanguard

Bhattacharjee, D. (January 2015) China Pakistan Economic Corridor. Retrieved from the website: file://C:/Users/hp/Downloads/SSRN-id2608927.pdf

CPEC News. (October 17, 2017). China-Pakistan Economic Corridor. Retrieved from the website: http:/cpecnews.com/china-pakistan-economic-corridor/.

CPGS (Centre for Pakistan and Gulf Studies). 2014. "Pakistan-China relations: prospects \& challenges" (roundtable report IV). February. <http://cpak gulf.org/wp-content/uploads/2014/02/Pak-China-Report.pdf>

Davids, I. (2005). Development theories: past and present. Pretoria, South Africa: Van Schaik. 
Dawn, (April, 2018). Balochistan being Neglected in CPEC. Retrieved from the website: https://www.dawn.com/news/1401117

Food Agriculture Organization. (1975). Environment and Sustainable Development. Retrieved From the NPTEL website: http://www.nptel.ac.in/courses/122102006/mod6/1.htm

Frederic, Grare (2006). Pakistan: The Resurgence of Baloch Nationalism, Carnegie Papers.

Iqbal, S. (2011). Pakistan-China Strategic Relation: Future Prospects (2009-2011), Department of Political Science, University of the Punjab, Lahore, Pakistan.

Khwaja, A. I. (2004). Is Increasing Community Participation Always a Good Thing? Journal of the European Economic Association, pp.427-436.

Liebenberg, S. \& Theron, F. (1997). Participatory Development Management and the RDP, Kenwyn, Juta.

Malik, Maria (2013). Balochistan Conundrum .Islamabad: Poorab Academy

Marsland, R. (2006). Community Participation: The Tanzanian Way, Conceptual Contiguity or Power, Oxford Development Studies, vol.34:1.

Malik, Yaser (2014). Strategic Importance of Gwadar Port. Journal of Political Studies, vol.19, pp.57-69.

Mehmood, M. (2016). China-Pakistan economic Corridor-The Geo-Strategic Dimension and Challenges. CISS Insight: Quarterly News \& Views.

Ministry of Planning Development and Reform. (Aug 19, 2017). CPEC. Retrieved from the website: http://www.pc.gov.pk/

Mustafa, Sadaf \& Zafar, Ammad (2017). China Pakistan Economic Corridor: Importance and Challenges for Pakistan and China. International Journal of Social Science and Economic Research, vol.02:11, pp.5059-5068.

Mustikhan, Abid (May 8, 2017). Is CPEC also a Game Changer for Balochistan? Retrieved from the website: https:/tribune.com.pk/story/1404001/cpecalso-game-changer-balochistan/ 
Pawan, Manohar (2014). Social and Community Development Practice. Saurabh Printers Pvt. Limed, Delhi.

Peerzada, Salman (February 04, 2012). Pakistan is a Resilient Country. Retrieved from the website:, http://www.dawn.com/news/693166

PILDAT (2012). Annual Report, Retrieved from the website: http://www.pildat.org/Publications/publication/AnnualReportAndNewsLet ter/Annual_Report_2014-15

Qamar, Khan (June 2, 2017). One Belt One Road-CPEC- Pakistan. Retrieved from the website: http://www.chinadaily.com.cn/opinion/2017beltandroad/ 2017-06/02/content_29598716.htm.

Tai, Michael (2017). Gwadar: A Case of South-South Cooperation. Cambridge Journal of Eurasian Studies, pp.1-12.

United Nations (1974). The Cocoyoc Declaration. United Nations Publication, New York.

United Nations Development Programs (UNDP) (2014). Human Development Report. Oxford University Press, New York.

UNDP. (June 20, 2016). Pakistan's New Poverty Index Reveals that 4 Out of 10 Pakistanis Live in Multidimensional Poverty. Retrieved from the website: http://www.pk.undp.org/content/pakistan/en/home/presscenter/pressrelease s/2016/06/20/pakistan-s-new-poverty-index-reveals-that-4-out-of-10pakistanis-live-in-multidimensional-poverty.html

World Bank (1990). World Development Report: Knowledge for Development. New York, USA: Oxford University Press.

Wang, J. (2015) 'China's 'New Silk road': A case study in Eu-China relations. In: Amighini, A. \& Berkofsky, A. ed', Xi's Policy Gambles: The Bumpy Road Ahead (pp. 92-109). Beijing: ISPI.

Willis, Katie. (2005). Theories and Practices of Development. Taylor \& Francis eLibrary, New York.

Zahir, Shah (2016). China-Pakistan Economic Corridor (CPEC) and its Importance, The Diplomatic Insight, Special Supplement on China Pakistan Economic Corridor, Volume 9, Issue 2, Pg\#10. 
Zimmerman, Thomas (2015). The New Silk Roads: China, the U.S., and the Future of Central Asia, Center On International Cooperation, New York University, Pg\#9.

Dr. Siraj Bashir is an Assistant Professor in the Department of Social Work, University of Balochistan, Quetta.

Dr. Muhammad Arshad is an Assistant Professor in the Department of Social Work, University of Karachi.

Sadia Barech is an Assistant Professor in the Department of Social Work, University of Balochistan Quetta. 